\title{
DAMPAK PEMBANGUNAN BYPASS IDA BAGUS MANTRA TERHADAP ALIH FUNGSI LAHAN PERTANIAN DI PROVINSI BALI
}

\author{
Putu Adi Suprapto \\ Politeknik Negeri Bali \\ Telp. (0361) 701981.E-mail: putuadisuprapto@gmail.co.id
}

\begin{abstract}
ABSTRAK
Pembangunan fasilitas umum berupa jalan arteri yang menghubungkan Kota Denpasar, Kabupaten Gianyar dan Kabupaten Klungkung mempunyai tujuan untuk mempermudah mobilitas penduduk sekitar kawasan tersebut. Jalan arteri sepanjang Tohpati-Kusamba yang lebih dikenal dengan nama Bypass Ida Bagus Mantra sejauh ini memang mampu memenuhi kepentingan masyarakat Bali, khususnya sebagai akses perekonomian dari pusat kota menuju Bali Timur. Namun demikian, saat ini dampak negatif dari pembangunan jalan tersebut tidak dapat dihindarkan lagi, buktinya jumlah alih fungsi (konversi) lahan pertanian menjadi non pertanian semakin meningkat. Letak strategis dan ekonomis dapat dikatakan sebagai faktor utama yang menyebabkan menjamurnya alih fungsi lahan di sepanjang bypass tersebut. Fakta ini didukung karena pada kenyataannya Bypass Ida Bagus Mantra selama ini tidak hanya menghubungkan kota dengan kabupaten yang ada di Provinsi Bali, akan tetapi juga merupakan akses yang menghubungkan Provinsi Bali dengan Provinsi Nusa Tenggara Barat, untuk itulah maka tidak berlebihan jika letak Bypass Ida Bagus Mantra dikatakan semakin strategis. Dari segi instrumen hukum, pengaturan daerah pada sebelah utara dan selatan di sepanjang jalan tersebut melalui Keputusan Gubernur Bali Nomor 16 Tahun 2002 ternyata tidak mampu mencegah dan menanggulangi terjadinya alih fungsi tersebut.

Kata Kunci: Pembangunan, Alih Fungsi, Lahan Pertanian
\end{abstract}

\begin{abstract}
The building of public facilities such as arterial road that connects Denpasar, Gianyar and Klungkung has purpose to facilitate people mobility around that area. Arterial roads along Tohpati-Kusamba named Ida Bagus Mantra Bypass are able to completed Balinese fullness, especialy as economic access from downtown to East Bali. However, the negative impact of the construction of the road can not be avoided, it is proof by number of conversion (conversion) agricultural land into non-agriculture are increased. The strategic location and economical can be regarded as a major factor that the reason of increasing conversion land along the bypass. This fact is supported by the fact that Ida Bagus Mantra Bypass has not only connects the city with the districts in Bali Province, but also the access to connects Bali province with Nusa Tenggara Barat, that is why it is not excessive if the location of the Ida Bagus Mantra Bypass are more strategic. From the legal instruments, the arrangement of the region on the north and south along the road based from Bali Governor Decree No. 16 of 2002 was not able to prevent and cope the change of these functions.
\end{abstract}

Keywords: construction, conversion, Agricultural Land 


\section{Pendahuluan}

Pertanian merupakan sektor yang sangat penting bagi Indonesia, mengingat sebagian besar makanan pokok dari rakyat Indonesia adalah nasi. Sudah sepatutnya jika pemerintah meningkatkan produktivitas sektor pertanian untuk meningkatkan dan menjamin ketahanan pangan Nasional. Di masa depan, kalkulasi Indonesia akan kekurangan beras jauh lebih realistis ketimbang surplus beras. Hal demikian didukung dengan kenyataan saat ini di Indonesia terjadi konversi lahan pertanian secara besar-besaran tanpa terkendali.

Menurut Data Resmi Sensus Penduduk Tahun 2010 yang dikeluarkan oleh Badan Pusat Statistik, jumlah penduduk Indonesia adalah 237.641.326 jiwa. Berangkat dari asumsi jumlah penduduk tadi, jika kita menggunakan data pertumbuhan penduduk indonesia yang dikeluarkan oleh bank dunia, yakni $1.49 \%$ per tahun, maka jumlah penduduk Indonesia Tahun 2014 ini akan menjadi 252.124 .458 jiwa. Jika rate pertumbuhan penduduk seperti ini terus berlanjut, maka pada Tahun 2025 jumlah penduduk indonesia akan menembus angka 300 juta jiwa. (http://ariwahyudiweb.id /jumlahpenduduk-indonesia/diakses pada 0512-2014).

Makin

pertambahan perkembangan ekonomi dan industri sejalan dengan mengakibatkan alih fungsi (konversi) lahan pertanian pangan. Hal itu secara langsung telah mengancam daya dukung wilayah secara nasional dalam menjaga kemandirian, ketahanan dan kedaulatan pangan.

Selama ini pemerintah selaku pemegang kekuasaan pemerintahan baik di pusat maupun di daerah telah melakukan upaya untuk menanggulangi permasalahan konversi lahan pertanian tersebut dengan menetapkan kebijakan dan peraturan perundang-undangan. Namun demikian, upaya tersebut dapat dikatakan tidak efektif mengingat kasus-kasus konversi lahan pertanian, khususnya di Provinsi Bali masih saja kerap terjadi. Dalam 5 (lima) tahun terakhir, luas dari sawah di Bali berkurang 1000 (seribu) Hektar per tahun. (http:// www.antarabali.com/berita/42210/kel angsungan-subak-di-masa-mendatang diakses pada 06-12-2014).

Konversi sawah tidak bida dipisahkan dengan pengadaan tanah untuk kepentingan umum yang dilakukan oleh pemerintah, seperti untuk pembangunan jalan, rumah sakit, pasar, sekolah, terminal, stasiun dan sarana umum lainnya. Pengadaan tanah untuk kepentingan umum secara hukum telah diatur dalam Peraturan Presiden Republik Indonesia Nomor 65 Tahun 2006 tentang Pengadaan Tanah bagi Pelaksanaan Pembangunan untuk Kepentingan Umum.

Dalam rangka memperlancar mobilitas penduduk di sekitar kawasan Kota Denpasar, Kabupaten Gianyar dan Kabupaten Klungkung, serta memperlancar arus transportasi yang menghubungkan Bali dengan Lombok, maka dilaksanakan proyek pengadaan tanah untuk pembangunan 
jalan arteri yang saat ini bernama Bypass Ida Bagus Mantra, yang membentang dari Tohpati, Kota Denpasar menuju Kusamba, Kabupaten Klungkung, yang melalui Kota Denpasar, Kabupaten Gianyar dan Kabupaten Klungkung. Namun demikian efek negatif yang tidak dapat dihindarkan adalah terjadinya konversi sawah di kawasan sepanjang jalan arteri tersebut, misalkan saja di daerah yang termasuk Kecamatan Sukawati sampai Kecamatan Gianyar, terjadi pembangunan-pembangunan fisik di atas area yang sebelumnya adalah sawah. (http:// www.balipost.co.id/mediadetail.php?m odule $=$ detailberitaminggu\& $\mathrm{kid}=2 \& i d=4$ 8602 diakses pada 04-12-2014).

Dengan melihat paparan di atas, maka penulis merasa tertarik untuk mengkaji dan membahas permasalahan terkait alih fungsi lahan pertanian di sepanjang jalan Bypass Ida Bagus Mantra.

\section{Tinjauan Umum Tentang Pengadaan Tanah Untuk Kepentingan Umum}

Pengadaan tanah merupakan perbuatan pemerintah untuk memperoleh tanah untuk berbagai kepentingan pembangunan, khususnya bagi kepentingan umum. Pada prinsipnya pengadaan tanah dilakukan dengan cara musyawarah antara pihak yang memerlukan tanah dan pemegang hak atas tanah yang tanahnya diperlukan untuk kegiatan pembangunan. (Maria Sumardjono, 2008: 280).

Berdasarkan data dari Dinas Pekerjaan Umum Provinsi Bali Tahun
1991, proyek pengadaan tanah untuk kepentingan pembangunan jalan arteri sepanjang Tohpati-Kusamba, yang saat ini bernama Bypass Ida Bagus Mantra memiliki panjang 26,22 (dua puluh enam koma dua dua) $\mathrm{km}$ dengan lebar daerah milik jalan (damija) 40 (empat puluh) meter, meliputi 3 (tiga) kabupaten/kota, yaitu Kota Denpasar, Kabupaten Gianyar dan Kabupaten Klungkung. Proyek pengadaan tanah tersebut dilakukan secara bertahap mulai Tahun Anggaran 1991/1992 di Kota Denpasar sampai dengan Tahun Anggaran 2002 di Kabupaten Klungkung. Proyek pengadaan tanah tersebut dilakukan melalui cara pembebasan atau pelepasan hak, dengan pemberian ganti kerugian kepada para pemilik tanah. Besarnya ganti kerugian ditentukan melalui musyawarah antara para pemilik tanah dengan instansi berwenang yang memerlukan tanah, dengan bantuan dan Panitia Pengadaan Tanah. Pada kenyataannya bentuk dan besar ganti kerugian yang diberikan untuk pelepasan hak atas tanah yang terkena proyek tersebut adalah tidak sama, karena rentang waktu pelaksanaan proyek dimaksud cukup lama yaitu mulai Tahun 1991 sampai dengan Tahun 2002.

Pada umumnya proses pengadaan tanah dan pemberian ganti kerugian atas tanah yang dilepaskan haknya oleh para pemilik tanah kepada pemerintah inilah yang selalu menjadi permasalahan, karena jumlahnya tidak pernah memadai atau terpaut cukup banyak dengan harga pasar dan diyakini tidak akan dapat mempertahankan

apalagi 
meningkatkan taraf hidup bekas pemilik tanah.

\section{Pembahasan}

Alih Fungsi Lahan Pertanian di Sepanjang Jalan Bypass Ida Bagus Mantra

Bypass Ida Bagus Mantra adalah jalan arteri yang menghubungkan Kota Denpasar yang berstatus Pusat Kegiatan Nasional (PKN) dengan wilayah Bali Bagian Timur. Menurut ketentuan Pasal 1 angka 18 Keputusan Gubernur Provinsi Bali Nomor 16 Tahun 2002 tentang Rencana Detail Tata Ruang Kawasan Sepanjang Jalan Arteri Tohpati-Kusamba, menyatakan bahwa: "18. Jalan Arteri Primer, adalah jalan yang menghubungkan secara menerus kota jenjang kesatu dengan kota jenjang kedua dengan syarat kecepatan paling rendah $60 \mathrm{~km} / \mathrm{jam}$, tidak terganggu oleh laiu iintas lokal dan jarak antar titik persimpangan jalan dibatasi secara efisien sesuai ketentuan yang berlaku". Jalan Arteri tersebut juga merupakan jalur operasional aktivitas regional yang mengubungkan Pulau Jawa dengan Nusa Tenggara Barat (NTB). Berdasarkan data Dinas Pekerjaan Umum Provinsi Bali pada tahun 1990, diperoleh informasi bahwa sebelum dilaksanakan proyek pengadaan (pembebasan tanah) untuk pembangunan jalan bypass, penggunaan tanah di sepanjang dan sekitar jalan tersebut hampir semua diperuntukkan untuk lahan pertanian. Berdasarkan Undang-Undang Republik Indonesia Nomor 41 Tahun 2009 tentang Perlindungan Lahan Pangan Berkelanjutan, ketentuan Pasal 1 angka 1, berbunyi: "Lahan adalah bagian daratan dari permukaan bumi sebagai suatu lingkungan fisik yang meliputi tanah beserta segenap faktor yang mempengaruhi penggunaannya seperti iklim, relief, aspek geologi, dan hidrologi yang terbentuk secara alami maupun akibat pengaruh manusia." Selanjutnya terkait pengertian lahan pertanian dapat dicermati pada ketentuan angka 2 berbunyi: "Lahan Pertanian adalah bidang lahan yang digunakan untuk usaha pertanian"

Pasca proyek pengadaan tanah, terutama setelah dibuka jalan arteri sepanjang Tohpati-Kusamba, terdapat banyak terjadi perubahan penggunaan lahan (alih fungsi lahan) yang semula adalah lahan pertanian kemudian berubah menjadi tanah non-pertanian, seperti: art shop, toko, perumahan atau pemukiman, tempat-tempat usaha, perkantoran swasta, restoran, spa dan fasilitas penunjang pariwisata lainnya.

Adapun tanah-tanah yang terkena proyek pengadaan tanah dimaksud adalah semuanya merupakan tanah pertanian (sawah) produktif dan hampir semua mempunyai irigasi teknis. Dalam Foto 1 di bawah ini akan menggambarkan alih fungsi lahan pertanian ke nonpertanian akibat pembangunan jalan arteri atau Bypass Ida Bagus Mantra.

Tanah yang berada di kawasan sepanjang Jalan Tohpati-Kusamba sebagian besar adalah tanah Hak Milik masyarakat yang memberi wewenang kepada pemegang hak atau pemilik tanah untuk mempergunakan tanah yang bersangkutan, demikian pula tubuh bumi dan air serta ruang yang 
ada di atasnya jika diperlukan untuk kepentingan yang langsung berhubungan dengan penggunaan tanah itu dalam batas-batas menurut peraturan-peraturan hukum yang berlaku. Dalam hubungan ini akan terjadi benturan kepentingan (conflict of interest) antara kepentingan pengaturan pemanfaatan ruang yang membawa konsekuensi pembatasan pemanfaatan ruang dengan kewenangan penggunaan tanah dalam rangka pelaksanaan hak atas tanah oleh pemilik tanah yang berada di sepanjang Bypass Ida Bagus Mantra.

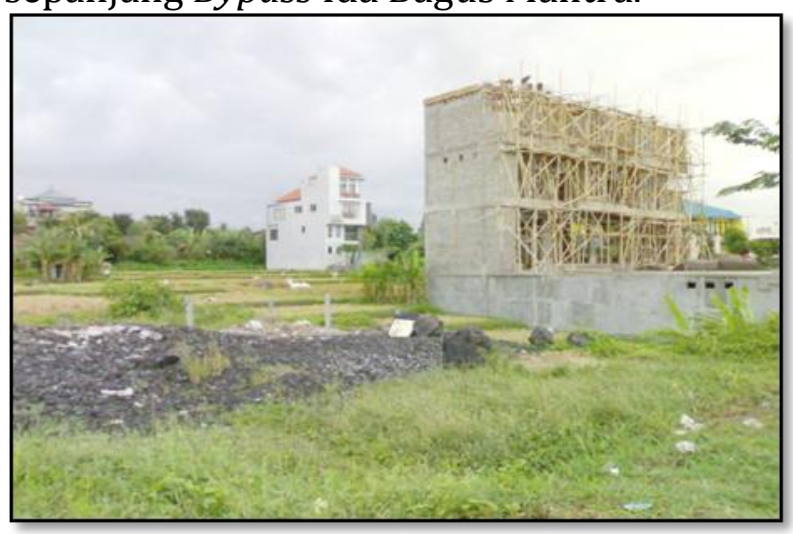

Foto 1 kawasan yang dulu merupakan lahan pertanian yang sekarang beralih fungsi menjadi bangunan fisik permanen atau lahan dengan fungsi non pertanian.

Saat ini di sekitar kawasan bypass tersebut, pemanfaatan tanah oleh pemilik tanah cenderung tidak terkendali, buktinya di sepanjang daerah Tohpati-Kusamba semakin hari semakin berjejer bangunan dengan tidak memperhatikan atau mengenyampingkan kebijakan larangan membangun dari pemerintah. Tetapi karena kebutuhan dan pertimbangan ekonomi tetap saja terjadi alih fungsi lahan. Pola perkembangan pemukiman di Indonesia mengarah ke wilayahwilayah jalur transportasi seperti jalan, apalagi jalan besar seperti ini yang menghubungkan jalur transportasi antara Provinsi Bali dengan Provinsi Lombok.

Pasca pemberlakuan sitem otonomi daerah Tahun 1999, pemerintah daerah berwenang dalam penetapan terhadap pemanfaatan hak atas tanah dengan memberikan suatu batasan-batasan, melalui berbagai instrumen seperti: Rencana Tata Ruang/Tata Guna Tanah, ketentuan mengenai garis sempadan, penetapan kawasan hijau, penetapan ruang terbuka hijau, penetapan kawasan lindung, penetapan batas tinggi bangunan dan lain sebagainya. Pembatasan bagi kewenangan penggunaan tanah memang tetap mempertimbangkan kepentingan masyarakat, khususnya para pemilik tanah.

Penggunaan tanah untuk tempat usaha karena letak tanah tang strategis akan jauh lebih dirasa menguntungkan dari segi ekonomi, daripada penggunaannya hanya untuk lahan pertanian. Kebijakan yang dirumuskan dan ditetapkan oleh pemerintah maupun pemerintah daerah seyogyanya harus mampu mengakomodir beberapa kepentingan, terutama kepentingan umum. Hal demikian tentunya akan mempermudah dalam menciptakan ketertiban dalam tataran implementasinya. Selain menciptakan ketertiban, kebijakan tersebut juga akan dapat berjalan dengan baik dan memberikan manfaat bagi masyarakat 
luas. Apalagi hak kepemilikan dalam hal ini hak milik atas tanah adalah salah satu hak yang tidak boleh secara semena-mena dibatasi pelaksanaannya oleh siapapun termasuk oleh negara. (Boedi Harsono, 2003: 296-297).

Pada umumnya alih fungsi lahan cenderung menular dan meningkat serta disebabkan oleh 2 (dua) faktor terkait. Pertama, sejalan dengan pembangunan kawasan jalan, perumahan atau industri di suatu lokasi yang beralih fungsi, maka aksesibilitas di lokasi tersebut semakin mendorong meningkatnya permintaan lahan oleh investor lain atau spekulan tanah sehingga harga lahan di sekitarnya meningkat. Kedua, meningkatnya harga lahan selanjutnya mendorong petani lain di sekitarnya untuk menjual lahannya. Pembeli tanah tersebut biasanya bukan penduduk setempat sehingga akan terbentuk lahan-lahan yang secara umum rentan terhadap proses alih fungsi lahan. (B. Irawan, dkk., 2002: 5).

\section{Upaya Pemerintah Provinsi Bali Dalam Rangka Mencegah Alih Fungsi Lahan Pertanian di Bypass Ida Bagus Mantra}

Kawasan sepanjang jalan Tohpati-Kusamba, disatu sisi memang memiliki potensi pengembangan sektor perekonomian yang sangat besar dan disisi lain rencana tata ruangnya perlu dikelola dengan arif dan bijaksana dengan mewujudkan fungsi jalan arteri primer sesuai dengan standar yang berlaku, mengindari alih fungsi lahan sawah beririgasi teknis, pemeliharaan kelestarian lingkungan serta tetap menjaga kehidupan sosial budaya dan keagamaan setempat dan untuk maksud tersebut RDTR kawasan sepanjang Jalan Tohpati-Kusamba diharapkan menjadi suatu alat pengendali pemanfaatan ruang yang lebih terpadu dan operasional.

Dalam melakukan pengendalian dan perlindungan terhadap pemanfaatan kawasan di sebelah utara dan selatan sepanjang jalan Bypass Tohpati-Kusamba, yang sekarang diberi nama Jalan Profesor Doktor Ida Bagus Mantra, yang meliputi 3 (tiga) wilayah Kabupaten/Kota yakni Kota Denpasar, Kabupaten Gianyar dan Kabupaten Klungkung, Rencana Detail Tata Ruang Kawasannya, maka pemerintah Provinsi Bali menerbitkan Keputusan Gubernur Bali Nomor 16 Tahun 2002 tentang Rencana Detail Tata Ruang Kawasan Sepanjang Jalan Arteri Tohpati-Kusamba, sebagai kebijakan Pemerintah Provinsi Bali dalam pengaturan pemanfaatan ruang pada kawasan tersebut.

Rencana Detail Tata Ruang Kawasan Sepanjang Jalan Arteri Tohpati-Kusamba ditetapkan sebagai upaya untuk mendayagunakan, menjabarkan dan mensinkronkan kebijakan yang tertuang di dalam Rencana Tata Ruang Wilayah (RTRW) Provinsi Bali, RTRW Kota Denpasar, RTRW Kabupaten Gianyar dan RTRW Kabupaten Klungkung dan sebagai alat pengendali pemanfaatan ruang yang lebih terpadu dan operasional.

Adapun tujuan pemanfaatan ruang kawasan sepanjang Jalan Tohpati-Kusamba, sebagaimana dimaksud di dalam ketentuan Pasal 6 
Keputusan Gubernur Provinsi Bali Nomor 16 Tahun 2002, yaitu:

a) Terselenggaranya pemanfaatan ruang kawasan yang berkelanjutan dan berwawasan lingkungan sesuai dengan kemampuan daya dukung dan daya tampung lingkungan hidup serta sesuai dengan kebijaksanaan pembangunan nasional dan daerah;

b) Terselenggaranya pengaturan pemanfaatan ruang menurut kawasan lindung dan kawasan budidaya berdasarkan fungsifungsi kawasan yang ditetapkan di sepanjang jalur jalan arteri tohpati-kusamba;

c) Terwujudnya keterpaduan dalam penggunaan sumberdaya alam dan sumberdaya buatan dengan memperhatikan sumberdaya manusia;

d) Terwujudnya kehidupan masyarakat yang sejahtera;

e) Terwujudnya fungsi jalan arteri primer, kelestarian lingkungan dan budaya setempat.

Rencana pemanfaatan ruang kawasan sepanjang jalan arteri Tohpati-Kusamba ditetapkan untuk 2 (dua) kawasan yaitu kawasan lindung dan kawasan budidaya. Jenis-jenis komponen kawasan lindung meliputi:

1. Kawasan lindung setempat, terdiri dari:

a. kawasan sempadan pantai;

b. kawasan sempadan sungai;

c. kawasan radius kesucian pura;

d. kawasan sempadan pembatasan wilayah.

2. Kawasan rawan bencana.
Sedangkan jenis-jenis komponen kawasan budidaya meliputi :

1. Kawasan pertanian tanaman pangan lahan basah;

2. Kawasan pertanian tanaman pangan lahan kering;

3. Kawasan pertanian tanaman tahunan atau perkebunan;

4. Kawasan budidaya perikanan;

5. Kawasan budidaya pertambangan;

6. Kawasan budidaya perindustrian;

7. Kawasan budidaya pariwisata;

8. Kawasan budidaya permukiman. Kebijaksanaan pemanfaatan ruang kawasan sepanjang jalan arteri Tohpati-Kusamba, yang berkaitan dengan pencegahan alih fungsi lahan, khususnya alih fungsi lahan pertanian menjadi non-pertanian, dapat dilihat dalam beberapa pasal dari surat keputusan Gubernur Bali Nomor 16 Tahun 2002, yaitu:

1) Pada Pasal 25 ayat (3) huruf e yang berbunyi: "Pencegahan dan membatasi alih fungsi lahan sawah produktif untuk kegiatan budidaya lainnya

(seperti: akomodasi/fasilitas pariwisata, industri, perumahah skala besar) kecuali untuk penyediaan prasarana umum yang menunjang fungsi jalan dan pengembangan kawasan yang sangat strategis untuk kepentingan umum untuk menunjang kesejahteraan masyarakat setempat."

2) Pada Pasal 34 ayat (2) yang berbunyi: "Pengembangan kegiatan budidaya non-pertanian diarahkan pada bagian utara jalan arteri dengan tetap menghindari alih fungsi lahan sawah beririgasi teknis." 
3) Pada Pasal 34 ayat (3) yang berbunyi: "Pada bagian selatan jalan Tohpati Kusamba, hampir seluruh ruas ditetapkan sebagai RTH KDB 0\% setebal 200 meter dari badan jalan terkecuali untuk penyediaan prasarana umum yang menunjang pengamanan fungsi jalan."

Pada foto disamping akan disajikan bahwa penggunaan tanah setelah dibangun jalan arteri TohpatiKusamba, telah mengakibatkan terjadi alih fungsi lahan pertanian produktif menjadi tanah non-pertanian. Foto ini akan menunjukkan bangunan permanen yang baru berada di sebelah selatan jalan, yang menurut pengaturan penggunaan ruangnya adalah untuk Ruang Terbuka Hijau (RTH) dengan Koefisien Dasar Bangunan (KDB) 0\% atau tidak boleh ada bangunan sama sekali.

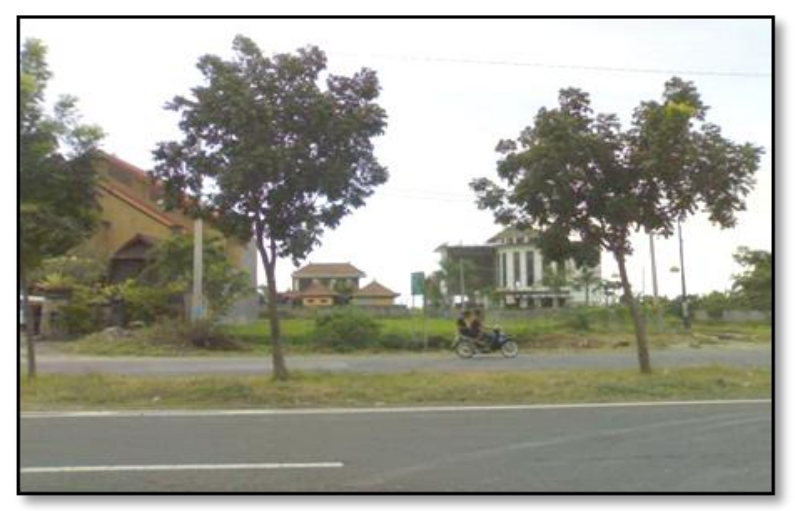

Jika melihat banyaknya pelanggaran khususnya alih fungsi lahan pertanian di sepanjang jalan Bypass Ida Bagus Mantra, baik di bagian selatan dan bagian utara jalan, membuktikan upaya pemerintah Provinsi Bali, Kota Denpasar, Kabupaten Gianyar dan Kabupaten Klungkung belum optimal dalam hal perlindungan dan konservasi terhadap lahan pertanian yang ada di sepanjang jalan arteri tersebut.

Hal yang paling diwaspadai bersama adalah jangan sampai nantinya ada kesan saling "lempar" tanggung jawab dan "tutup mata" antara Pemerintah Provinsi dengan Pemerintah Kabupaten dan Kota terkait. Kalau penyimpangan yang mengarah pada pelanggaran hukum ini dibiarkan berlarut-larut, maka ke depannya, siapapun pemerintahnya berpotensi akan mengalami kesulitan dalam bersikap tegas terhadap kasus pelanggaran hukum yang terjadi. Apalagi semakin hari jumlah pelanggar semakin bertambah dan dengan tingkat pelanggaran yang berbedabeda. Banyak pengusaha yang hendak memanfaatkan lahan di sekitar jalan arteri Tohpati-Kusamba untuk kepentingan bisnis, karena semakin strategisnya kawasan tersebut. Namun, yang perlu diketahui bersama adalah semangat dari jajaran pemerintah provinsi sampai pada pemerintah kota dan kabupaten terkait semestinya sejalan dengan semangat dan ketentuan dasar yang mengatur kawasan tersebut, yaitu ketentuan Keputusan Gubernur Nomor 16 tahun 2002 tentang Rencana Detail Tata Ruang Kawasan Sepanjang Jalan Arteri TohpatiKusamba, yang mana penataan jalur Tohpati-Kusamba tidak membenarkan adanya bangunan di sebelah selatan jalan dan hanya memberikan KDB $30 \%$ di sebelah utara jalan.

Saat ini tidak berlebihan jika dikatakan bahwa aturan yang ada terkesan tidak bertaring, sebab kawasan sepatutnya diperuntukkan 
sebagai Ruang Terbuka Hijau, malah dialih fungsikan, lambat laun Ruang Terbuka Hijau itupun pasti akan habis. Dilain sisi Pemerintah daerah terkait seyogyanya memulai merencanakan dan selanjutnya melaksanakan langkah nyata guna mengantisipasi dan menindaklanjuti pelanggaran yang akan dan telah terjadi.

Dengan adanya berbagai indikasi pelanggaran di sepanjang Bypass Ida Bagus Mantra, tidak berlebihan jika dikatakan pembentukan Rencana Detail Tata Ruang Kawasan Sepanjang Jalan Arteri Tohpati-Kusamba ditetapkan sebagai upaya untuk mendayagunakan, menjabarkan dan mensinkronkan kebijakan yang tertuang di dalam Rencana Tata Ruang Wilayah (RTRW) Provinsi Bali, RTRW Kota Denpasar, RTRW Kabupaten Gianyar dan RTRW Kabupaten Klungkung dan sebagai alat pengendali pemanfaatan ruang yang lebih terpadu dan operasional kurang dapat berjalan.

Terdapat 3 (tiga) kendala mendasar yang menjadi alasan peraturan pengendalian alih fungsi lahan sulit dilaksanakan yaitu: (L. I. Nasoetion, 2003: 24).

a. Kebijakan yang kontradiktif terjadi karena di satu pihak pemerintah berupaya melarang terjadinya alih fungsi, tetapi di sisi lain kebijakan pertumbuhan industri/manufaktur dan sektor non pertanian lainnya justru mendorong terjadinya alih fungsi lahan-lahan pertanian.

b. Cakupan kebijakan yang terbatas, Peraturan-peraturan tersebut di atas baru dikenakan terhadap perusahaan-perusahaan atau badan hukum yang akan menggunakan tanah dan/atau akan merubah tanah pertanian ke non pertanian. Perubahan penggunaan tanah sawah ke non-pertanian yang dilakukan secara individual atau peorangan belum tersentuh oleh peraturan-peraturan tersebut. Padahal perubahan fungsi lahan yang dilakukan secara individual secara langsung diperkirakan cukup luas.

c. Kendala konsistensi perencanaan disebabkan karena Rencana Tata Ruang Wilayah (RTRW) yang dilanjutkan dengan mekanisme pemberian ijin lokasi adalah instrumen utama dalam pengendalian untuk mencegah terjadinya konversi lahan sawah beririgasi teknis. Dalam kenyataannya banyak RTRW yang justru merencanakan untuk mengkonversi tanah sawah beririgasi teknis menjadi non pertanian.

Jelas bahwa meskipun pengaturan kawasan di sepanjang kanan dan kiri jalan Bypass Ida Bagus Mantra telah dimuat dalam Keputusan Gubernur Bali Nomor 16 Tahun 2002, akan tetapi pengaturan tersebut tidak mampun membendung kendala mendasar yang menjadi alasan peraturan pengendalian alih fungsi lahan sulit dilaksanakan, yang tentunya mengakibatkan kedudukan pengaturan alih fungsi lahan pertanian akan lemah. Sejauh ini ketiga kendala mendasar tersebut (L. I. Nasoetion) memang sangat dirasakan terhadap pencegahan alih fungsi lahan pertanian di sepanjang jalan Bypass 
Ida Bagus Mantra. Selain itu, kurangnya pengawasan dan koordinasi dari jajaran terkait, dalam hal ini Pemerintah Provinsi Bali dengan Pemerintah Kota Denpasar, Kabupaten Gianyar, dan Kabupaten Klungkung, menyebabkan perlindungan terhadap lahan pertanian di sepanjang jalan tersebut tidak dapat berjalan dengan maksimal.

Selain melalui pembentukan Keputusan Gubernur Bali Nomor 16 Tahun 2002 tentang Rencana Detail Tata Ruang Kawasan Sepanjang Jalan Arteri Tohpati-Kusamba, sejauh ini dapat dikatakan belum adanya upaya penyelamatan dan perlindungan dalam hal konservasi lahan pertanian di sepanjang jalan Bypass Ida Bagus Mantra. Dari data yang diperoleh melalui pengamatan di jalan Bypass tersebut, memperlihatkan sekitar $60 \%$ lahan pertanian di sebelah utara dan selatan jalan tersebut telah berubah fungsi menjadi lahan non-pertanian serta semakin hari kasus alih fungsi lahan pertanian ini semakin bertambah banyak.

Akibat lain dari pengalihfungsian peruntukan lahan pertanian menjadi non-pertanian di beberapa daerah di sepanjang jalan Bypass Ida Bagus Mantra secara langsung akan mematikan organisasi petani (subak), hal itu dikarenakan luas lahan pertanian mereka semakin menyempit, akibat banyak yang beralaih fungsi. Hal itu tentunya secara umum akan berimbas pada produksi pangan di Provinsi Bali, meskipun sampai saat ini belum dirasakan kelangkaan pangan di Provinsi Bali. Akan tetapi jika hal ini dibiarkan saja, tanpa adanya langkah dari pemerintah dalam mencegah alih fungsi kawasan pertanian, sedangkan pertumbuhan penduduk akan semakin meningkat, rasanya memungkinkan akan terjadi kelangkaan pangan di Bali. Hal ini sesuai dengan pendapat S.C. Wibowo, yang menyatakan bahwa alih fungsi lahan pertanian yang semakin bertambah dan tidak terkendali akan mempengaruhi produksi dan ketersedian pangan di suatu daerah (S.C. Wibowo, 1996: 18). Padahal tidak semua daerah di Indonesia memiliki tingkat kesuburan tanah yang baik, hanya di Jawa, Bali, dan sebagian Sumatera yang memiliki tingkat kesuburan yang baik dalam melakukan produksi pangan khususnya beras.

Analisa lain yang dapat dijabarkan pada kasus ini adalah dengan ditetapkan pengaturan Tata Lingkungan Kawasan pada bagian selatan jalan Tohpati-Kusamba sebagai RTH KDB 0\%, memang mengakibatkan para pemilik tanah tidak dapat leluasa menggunakan tanahnya untuk memenuhi kebutuhan hidupnya, apalagi bagi mereka yang telah merelakan tanahnya dibeli dan diperuntukkan untuk jalan tersebut dengan nilai ganti rugi yang relatif kecil dan sisa tanahnya sekarang tidak memungkinkan atau tidak produktif lagi, bila tanahnya dipergunakan untuk pertanian karena luasnya kecil, sehingga mereka memerlukan pemanfaatan tanahnya untuk penggunaan selain sebagai tanah pertanian untuk dapat memberikan hasil yang lebih baik dalam rangka untuk memperbaiki kesejahterannya. Melihat kenyataan tersebut, maka 
perlu kiranya dipertimbangkan oleh pemerintah daerah terkait (policy stakeholders) dalam merumuskan kebijakan mengenai rencana pemanfaatan ruang kawasan sepanjang jalan Tohpati-Kusamba. Kepentingan para pemilik tanah yang sisanya tanahnya tidak efektif bila dipergunakan untuk pertanian, dapat diberikan dispensasi agar tanahnya dapat dipergunakan untuk bangunan tempat usaha, sehingga kebijakan pemerintah baik dalam tataran perumusan maupun implementasi kebijakan memperhatikan sistem nilai/moral yang ada pada semua anggota stakeholders kebijakan, dalam rangka untuk mecapai tujuan pemanfaatan ruang yakni mewujudkan kehidupan masyarakat yang sejahtera dan tidak justru menyengsarakan masyarakat.

Secara garis besar permasalahan dan pelanggaran alih fungsi lahan pertanian di jalan Bypass Ida Bagus Mantra memang diakibatkan lemahnya pengawasan dan koordinasi dari pemerintah daerah terkait. Pemerintah daerah semestinya melakukan langkah nyata untuk mengendalikan dan mencegah pelanggaran terkait alih fungsi lahan pertanian tersebut. Apabila dibiarkan begitu saja maka luas lahan pertanian di sebelah utara dan selatan jalan Bypass Ida Bagus Mantra akan semakin berkurang. Langkah awal yang bisa menjadi pertimbangan dari Pemerintahan Provinsi Bali adalah mengingat lokasi dari jalan ini berfungsi sebagai jalan lintas batas kabupaten/kota dan/atau lintas batas provinsi, maka pemerintah daerah dapat melakukan koordinasi dan mensingkronkan kewenangan dan tanggung jawab antara Pemerintah Provinsi dengan Pemerintah Kabupaten/Kota yang terkait. Dalam hal, fokus kinerja pemerintah terkait bukan semata-mata terhadap pengalih-fungsian lahan pertanian menjadi lahan non pertanian yang telah terjadi, melainkan lebih pada konservasi atau perlindungan lahan pertanian yang belum beralih fungsi.

Untuk mencegah terjadinya alih fungsi lahan pertanian menjadi nonpertanian, seharusnya Pemerintah Provinsi Bali dan Pemerintah Kabupaten/Kota terkait, lebih melakukan pengawasan dan pengamatan (survey) langsung di sepanjang jalan Tohpati-Kusamba, hal ini dilakukan untuk mencegah terjadinya alih fungsi tersebut. Pemerintah daerah juga sebenarnya harus mampu memberdayakan peran serta dari masyarakat dalam pengawasan alih fungsi kawasan, misalkan saja dengan organisasi petani tradisional yang ada di Bali, sehingga tindakan pemerintah lebih bersifat preventif, bukan represif.

Secara Nasional, mulai tahun 2009 telah muncul konsep perlindungan lahan pertanian berkelanjutan, yang ditandai dengan terbitnya Undang-Undang Republik Indonesia Nomor 41 Tahun 2009 tentang Perlindungan Lahan Pertanian Pangan Berkelanjutan. Pada ketentuan Pasal 1 angka 3, menyatakan bahwa: "Lahan Pertanian Pangan Berkelanjutan adalah bidang lahan pertanian yang ditetapkan untuk dilindungi dan dikembangkan secara 
konsisten guna menghasilkan pangan pokok bagi kemandirian, ketahanan, dan kedaulatan pangan nasional. Selanjutnya dalam ketentuan Pasal 1 angka 5 Undang-Undang Republik Indonesia Nomor 41 Tahun 2009, dinyatakan: "Perlindungan Lahan Pertanian Pangan Berkelanjutan adalah sistem dan proses dalam merencanakan dan menetapkan, mengembangkan, memanfaatkan dan membina, mengendalikan, dan mengawasi lahan pertanian pangan dan kawasannya secara berkelanjutan."

Dari kedua ketentuan di atas tersebut, maka dapat dikatakan bahwa Pemerintah secara nasional ingin melakukan upaya untuk mencegah terjadinya alih fungsi lahan pertanian. Hal itu semakin dipertegas dalam ketentuan Pasal 44 ayat (1) UndangUndang tentang Perlindungan Lahan Pertanian Berkelanjutan, yang menyatakan bahwa: "Lahan yang sudah ditetapkan sebagai Lahan Pertanian Pangan Berkelanjutan dilindungi dan dilarang dialihfungsikan. Substansi ini tentunya dimaksudkan untuk melakukan pencegahan alih fungsi lahan pertanian yang bertujuan untuk menjaga ketersediaan atas lahan pertanian. Namun menurut teori yang ada, bagaimanapun bagusnya peraturan atau hukumnya, jika tidak diimbangi oleh masyarakat sadar hukum, maka niscaya akan menimbulkan keadaan tertib hukum. Sebenarnya dengan ditetapkannya Keputusan Gubernur Nomor 16 tahun 2002, yang menetapkan Ruang Terbuka Hijau dengan KDB 0\% setebal
200 meter saja, jika dipatuhi akan mampu mencegah alih fungsi lahan, untuk itu harus dilakukan upaya lain yang lebih menitik beratkan pada usaha agar masyarakat pemilik tanah semakin sadar akan adanya pengaturan tersebut serta mematuhinya. Namun demikian perlu diakui semangat Undang-Undang Republik Indonesia Nomor 41 Tahun 2009 tentang Perlindungan Lahan Pertanian Berkelanjutan ini sangat baik yaitu sebagai payung hukum untuk pertanian berkelanjutan, akan tetapi diperlukan segera peraturanperaturan lain yang menjabarkan lebih mengkhusus ketentuan ini, dari pusat sampai ke daerah. Menarik untuk ditunggu apakah langkah nyata yang akan dilakukan jajaran pemerintah daerah terkait untuk mencegah dan/atau setidaknya meminimalisir terjadinya kasus alih fungsi pertanian di kawasan jalan Bypass Ida Bagus Mantra.

\section{Simpulan}

Setelah proyek pembangunan jalan Bypass Tohpati Ida Bagus Mantra mengakibatkan terjadi banyak alih fungsi peruntukan lahan yang semula adalah lahan pertanian kemudian berubah menjadi lahan non-pertanian seperti: perumahan/pemukiman, tempat-tempat usaha, art shop, warung makan, cafe, spa dan fasilitas penunjang pariwisata.

Upaya Pemerintah Provinsi Bali, Kota Denpasar, Kabupaten Gianyar, dan Kabupaten Klungkung dalam rangka mencegah alih fungsi kawasan pertanian di bagian utara dan selatan sepanjang jalan Bypass Ida Bagus 
Mantra hanya dengan menerbitkan Keputusan Gubernur Provinsi Bali Nomor 16 Tahun 2002 tentang Rencana Detail Tata Ruang Kawasan Sepanjang Jalan Arteri TohpatiKusamba. Akan tetapi pelaksanaan Keputusan Gubernur Provinsi Bali Nomor 16 Tahun 2002 tersebut kurang efektif, karena lemahnya pengawasan dan koordinasi pemerintah terkait, ini dibuktikan dengan terjadinya alih fungsi lahan pertanian menjadi non-pertanian yang semakin hari jumlahnya semakin bertambah.

\section{Daftar Pustaka}

Direktorat Pangan dan Pertanian Kementerian Perencanaan Pembangunan Nasional/ Bappenas, 2006, Strategi Pengendalian Alih Fungsi Lahan Pertanian, Direktorat Pangan dan Pertanian Kementerian Perencanaan Pembangunan Nasional/ Bappenas, JakartaIrawan, B., dkk., 2002, Analisis Nilai Ekonomi Sumberdaya Lahan Pertanian, Pusat Penelitian Sosial Ekonomi Pertanian, Bogor

Harsono, Boedi, 2003, Hukum Agraria Indonesia, Sejarah Pembentukan Undang-undang Pokok Agraria, Isi dan Pelaksanaannya, Jilid 1 Hukum Tanah Nasional, Djambatan, Jakarta

Ridwan, Juniarso dan Sodik, Achmad, 2008, Hukum Tata Ruang dalam Konsep Kebijakan Otonomi Daerah, Nuansa, Bandung
Sumardjono, Maria, 2008, Tanah Dalam Perspektif Hak Ekonomi, Sosial dan Budaya, Kompas, Jakarta

Wibowo, S.C., 1996, Analisis Pola Konversi Sawah Serta Dampaknya Terhadap Produksi Beras, Institut Pertanian Bogor, Bogor

Nasoetion, L. I., 2003, Konversi Lahan Pertanian: Aspek Hukum dan Implementasinya, Makalah, Badan Penelitian dan Pengembangan Pertanian, Bogor

STPN Yogyakarta, 1996, Beberapa Catatan Mengenai Pelaksanaan Perencanaan Tata Ruang dan Penalagunaan Tanah, Makalah, Yogyakarta

Sukamdi, 2002, Kompleksitas Masalah Kependudukan di Indonesia, Makalah, Yogyakarta

Undang-Undang Nomor 5 Tahun 1960 tentang Peraturan Dasar PokokPokok Agraria

Undang-Undang Republik Indonesia Nomor 41 Tahun 2009 tentang Perlindungan Lahan Pertanian Berkelanjutan

Peraturan Presiden Nomor 65 Tahun 2006 tentang Pengadaan Tanah bagi Pelaksanaan Pembangunan untuk Kepentingan Umum

Keputusan Gubernur Bali Nomor 16 Tahun 2002 tentang Rencana Detail Tata Ruang Kawasan Sepanjang Jalan Arteri TohpatiKusamba

http://www.geocities.com/klinikfamilia /vasektomi1.html

http://www.nieuwsvanbali.nl/content/ content/overheidN.htm 